\title{
Aneta Stosik
}

Akademia Wychowania Fizycznego we Wrocławiu

e-mail: aneta.stosik@awf.wroc.pl

\section{OCZEKIWANIA NA RYNKU PRACY \\ W USLUGACH MEDYCZNYCH - WYZWANIA DLA PRACODAWCÓW}

\section{EXPECTATIONS ON THE LABOR MARKET IN MEDICAL SERVICES - CHALLENGES FOR EMPLOYERS}

DOI: $10.15611 /$ pn.2018.511.19

Streszczenie: Współdziałanie międzyorganizacyjne, relacje i ich zakres oraz tworzenie więzi $\mathrm{w}$ sieciach międzyorganizacyjnych stają się w ostatnich latach obszarem eksploracji badawczej w naukach o zarządzaniu. Jednocześnie pracownik i jego potencjał znalazł się w centrum szerokiej polemiki naukowej, zwłaszcza z powodu dominacji rynku pracownika w ostatnich latach. Troska nowoczesnej organizacji leży w zarządzaniu relacjami nie tylko $\mathrm{z}$ klientem zewnętrznym, ale przede wszystkim z klientem wewnętrznym, który w istotny sposób przyczynia się do budowania wartości dla organizacji. Celem artykułu jest identyfikacja współdziałania wysokospecjalistycznych klinik dentystycznych na konkurencyjnym rynku usług medycznych NZOZ w kontekście tworzenia wartości, jak również ukazanie relacji pracownik-pracodawca w nowoczesnym przedsiębiorstwie usługowym, w oparciu o badania empiryczne.

Słowa kluczowe: kapitał ludzki, współdziałanie, wyzwania, lekarze dentyści.

Summary: Inter-organizational cooperation, relations and their scope, as well as the creation of ties in inter-organizational networks have become, in recent years, an area of research exploration in management sciences. At the same time, the employee and their potential has found itself at the center of interest in a broad scientific polemics, especially in the period of the employee's market dominance in recent years. The concern of a modern organization lies in the management of relations not only with an external client but, above all, with an internal client, which significantly contributes to building value for the organization. The aim of the article is to identify the interaction of highly specialized dental clinics in the competitive market for Non-Public Health Care Institution's medical services in the context of value creation, as well as to show the employee-employer relationship in a modern service enterprise, based on empirical research.

Keywords: human capital, cooperation, challenges, dentists. 
Aneta Stosik

\section{Wstęp}

Ewolucja zmian rynkowych i pozycji człowieka w organizacji jest naturalną konsekwencją faktu, że to kapitał ludzki staje się głównym kreatorem wartości oraz czynnikiem determinującym pozycję konkurencyjną firmy. Podstawowym zasobem jest szeroko rozumiana wiedza i informacja, a będący jej nośnikiem pracownicy nie są traktowani wyłącznie jako źródło kosztów, lecz opłacalna inwestycja. W dużym stopniu to właśnie pracownicy wyznaczają wartość rynkową przedsiębiorstwa. Jednocześnie rozwój przedsiębiorstwa często jest spontaniczny i trudny do przewidzenia, a relacja pracownik-pracodawca w coraz większym zakresie zmienia kierunek z podległości służbowej na partnerski charakter współpracy i coraz częściej współdziałania identyfikowanego jako ,przejaw współpracy na rzecz wspólnego celu, z którym strony kooperujące się identyfikują" [Polak 2016, s. 286; Lipka 2004, s. 17]. Współdziałanie to bardziej zaawansowany rodzaj współpracy i oznacza „skoordynowane działanie nakierowane na realizację zadań cząstkowych wynikających z podziału pracy lub powiązań międzyorganizacyjnych powstałych w wyniku zawieranych umów i porozumień ułatwiających czy umożliwiających realizację określonych zadań" [Kaczmarek 2000, s. 5]. Celem artykułu jest identyfikacja preferencji pracowników wysokospecjalistycznych klinik, na rynku stomatologii NZOZ, w kontekście oczekiwań pracownika i pracodawcy ${ }^{1}$.

\section{Elastyczne modele biznesu w obliczu wyzwań współczesnego otoczenia}

Współczesne organizacje, które funkcjonują w warunkach niepewności, za determinantę sukcesu i warunek przetrwania uznają skuteczne i efektywne modele biznesu ${ }^{2}$. W warunkach współczesnej gospodarki istotne staje się umożliwianie realizacji be-

\footnotetext{
${ }^{1}$ Badania empiryczne prowadzone były w latach 2015-2017 na rynku wysokospecjalistycznych gabinetów stomatologicznych we Wrocławiu i w Katowicach - łącznie 12 klinik oraz wśród studentów ostatnich lat studiów Uniwersytetu Medycznego we Wrocławiu. W badaniach wzięło udział 47 studentów piątego roku studiów, Wydziału Stomatologii UM we Wrocławiu. Podstawową metodyką badań był sondaż diagnostyczny ze szczególnym uwzględnieniem kwestionariuszy wywiadów, kwestionariuszy ankiet oraz obserwacji uczestniczącej (case - dwie kliniki we Wrocławiu i Katowicach). Wybór klinik dokonany został celowo, zakwalifikowano do badania kliniki wielospecjalistyczne, wielogabinetowe, świadczące kompleksowe usługi w zakresie wszystkich procedur medycznych, posiadające m.in. 10-letni staż, należące do grupy NZOZ, współpracujące ze sobą na zasadach kontraktów relacyjnych.

${ }^{2}$ Model biznesu wg Falencikowskiego to ,wieloskładnikowy obiekt konceptualny opisujący prowadzenie biznesu poprzez opisanie logiki tworzenia wartości dla klienta i przechwytywania części tej wartości przez przedsiębiorstwo" [Falencikowski 2013, s. 37]. Model biznesowy jest narzędziem zawierającym zestaw elementów i relacji między nimi, w sposób schematyczny przedstawiającym pomysł na biznes. Stanowi zatem pewien schemat zjawiska w przeciwieństwie do strategii wyrażającej sposób działań i zachowań przedsiębiorstwa w stosunku do zmieniających się warunków otoczenia i jego wnętrza [Falencikowski 2013, s. 37].
} 
hawioralnych strategii wyłaniających, opartych na wykorzystywaniu szans i okazji [Sobińska 2015, s. 22-23]. Model będzie rozumiany tutaj jako sposób myślenia i działania, skierowany na niestandardowe, elastyczne rozwiązania, dzięki którym organizacja dokonuje zmian w sposób kreatywny, twórczy i innowacyjny. Powinien zakładać współistnienie kilku elementów, takich jak relacje klient-organizacja, organizacja-otoczenie oraz organizacja-pracownik, ukazanych na rys. 1 .

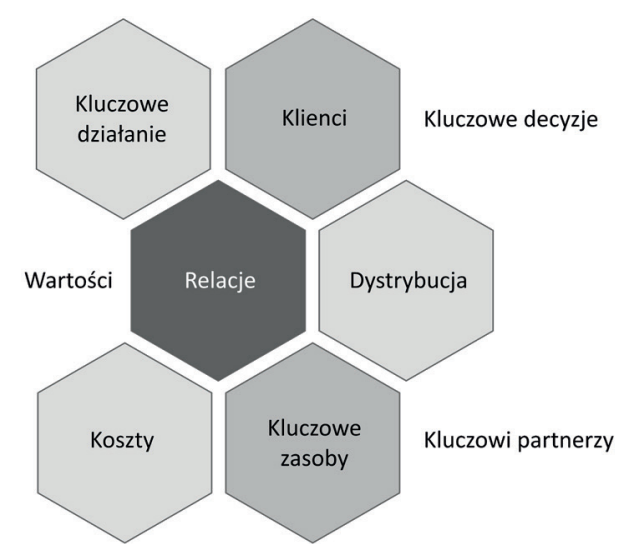

Rys. 1. Elementy modelu biznesu kreowane przez badane kliniki

Źródło: opracowanie na podstawie własnych badań empirycznych, za [Sobińska 2015, s. 25-26].

Model biznesu może się zatem jawić jako koncepcja kreacji wartości w firmie, która zakłada różnego typu zależności między różnymi grupami interesariuszy [Doligalski 2013, s. 28] i odpowiada na zasadnicze pytanie: „Jak przedsiębiorstwo kreuje wartość dla klienta?", zwracając uwagę na fakt, że współczesny rynek pracy kreuje pozycję klienta wewnętrznego - pracownika na wyższy poziom orientacji w przedsiębiorstwie. „Model biznesowy jest zbiorem założeń umożliwiających organizacji takie działania, które kreują wartość dla wszystkich graczy, od których jest ona zależna, co oznacza, że dana organizacja nie tworzy wartości wyłącznie dla klientów" [Magretta 2003, s. 44 i n.; 2002, s. 87-92]. Zmieniające się otoczenie organizacji sprawia, że zachodzi konieczność istotnego dostosowania się do potrzeb klienta zewnętrznego, jak również, w coraz większym stopniu, wewnętrznego, którym jest pracownik. $Z$ takiej perspektywy istnieje potrzeba weryfikacji dotychczasowych modeli biznesu w kontekście budowania relacji nie tylko z rynkiem klientów, ale również z rynkiem pracowników. Umiejętność definiowania ich przez organizację należy do kluczowych kompetencji w budowaniu wartości przedsiębiorstwa, jak również może istotnie wpływać na kwestie przetrwania organizacji oraz budowania jej przewag.

Otwartość na zmiany, zwłaszcza na rynku pracy, i szybkie reagowanie na płynące z niego sygnały stanowią jeden z głównych czynników sukcesu współczesnej 
organizacji. W zależności od koncepcji przyjmuje on różny wymiar. W przypadku konkurowania poprzez zarządzanie wiedzą i organizacyjne uczenie się jest on związany z wykorzystaniem wiedzy i doświadczeń w ciągłym przekształcaniu organizacji. Elastyczna jest ta organizacja, której zarówno kultura, jak i struktura dają szansę na szybkie dostosowanie się do zmieniających się potrzeb zarówno klientów, jak i pracowników. Skrócone procesy decyzyjne, spłaszczanie struktur, delegowanie uprawnień, partycypacyjny model zarządzania to atrybuty elastyczności i perspektywa przewagi [Brilman 2002, s. 391].

Wyzwanie, przed którym stoją współczesne organizacje, to podejście do budowania relacji pracodawca-pracownik, zwłaszcza w kontekście różnic międzypokoleniowych oraz istotnej w ostatnich latach zmiany oczekiwań młodego pokolenia pracowników. Wspomniana elastyczność zatem dotyczyć będzie szeroko rozumianego dostosowania się do wymogów rynku klientów - tych zewnętrznych, ale może przede wszystkim tych wewnętrznych. W związku z tym uznaje się, że elastyczność to również jedna z kluczowych kompetencji przedsiębiorstw, które są gotowe do budowania relacji sieciowych nie tylko z rynkiem, ale również z pracownikami. Elastyczność organizacyjną można osiągnąć dodatkowo poprzez minimum formalizacji oraz niewielką liczbę zasad kierujących zachowaniami ludzi. $Z$ totalną elastycznością należy utożsamiać: wykorzystywanie kreatywności pracowników, tolerancję niepewności i permanentną gotowość do zmian, stworzenie kultury organizacyjnej sprzyjającej szybkiemu dostosowaniu do wymagań klientów i konkurencji, we-

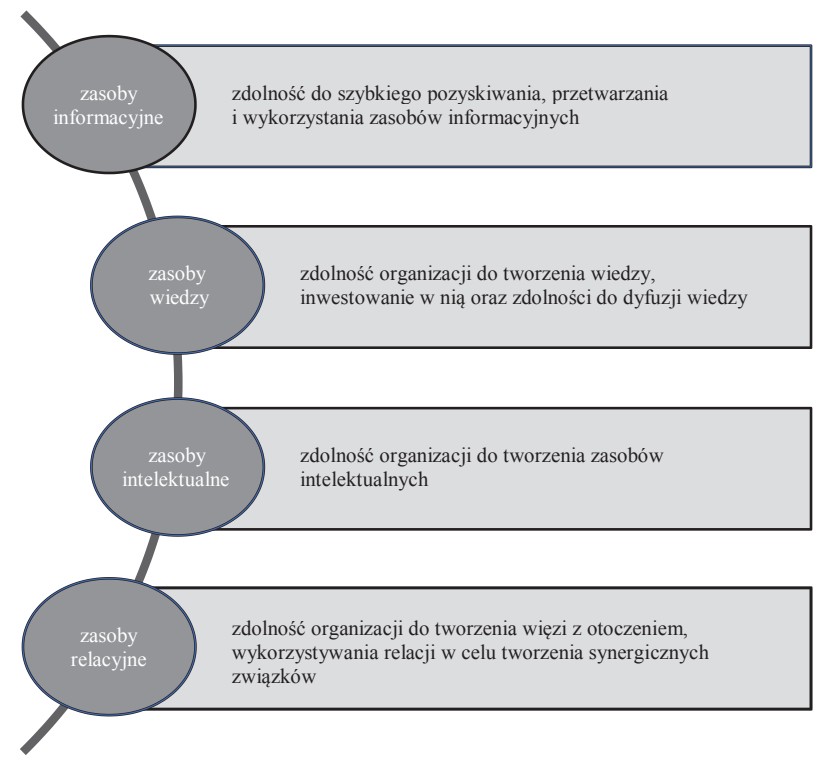

Rys. 2. Niematerialne wymiary elastyczności organizacji

Źródło: opracowanie własne na podstawie [Chomiak-Orsa 2013, s. 42]. 
wnętrzną niestabilność i twórczy chaos, akceptację różnorodności w organizacji, redundancję informacji i funkcji, pracę zespołową, autonomię ludzi i zespołów ludzkich oraz ciągłe gromadzenie informacji [Mikuła 2012, s. 1]. Wrażliwość współczesnej i nowocześnie zarządzanej organizacji leży w budowaniu nadmiaru zdolności do elastycznego reagowania na pojawiające się zagrożenia i szanse w otoczeniu organizacji. W aspekcie niematerialnym do wymiarów tej wrażliwości można zaliczyć: zasoby wiedzy, zasoby informacyjne, zasoby intelektualne oraz zasoby relacyjne (rys. 2).

Na zasoby relacyjne organizacji istotny wpływ ma zarówno kapitał relacyjny, jak również kapitał społeczny przedsiębiorstwa. Badane organizacje w celu uelastycznienia swoich działań wykorzystują, ukazane na rysunku 2, zasoby niematerialne. Stanowią one dla badanych firm adaptację do zmian w otoczeniu i pozwalają na szybsze wychwytywanie okazji. W badanych przedsiębiorstwach kapitał relacyjny i kapitał społeczny tworzą podstawy budowania kontraktów relacyjnych ${ }^{3} \mathrm{z}$ partnerami $\mathrm{w}$ biznesie, tworząc tym samym nowy rodzaj relacji między pracodawcą a pracownikiem.

\section{Pracownik na rynku pracy w usługach medycznych - refleksje z badań empirycznych}

Ostatnie lata obfitują w zmiany strukturalne rynku pracy, zwłaszcza jeśli chodzi o sposoby i formy zatrudnienia. Od kilku lat obserwuje się polepszenie sytuacji na rynku pracy, przejawiające się rosnącym zatrudnieniem i spadkami stopy bezrobocia (zob. raporty o pracy). Jednocześnie zmiany te powodują rosnące problemy organizacji z utrzymaniem pracownika na dłużej, jak również z samym procesem poszukiwania i zatrudniania nowych pracowników. Zmianie ulegają również trendy związane $\mathrm{z}$ formami zatrudnienia $\mathrm{w}$ poszczególnych branżach i sektorach gospodarki. Elastyczne formy zatrudnienia stają się coraz bardziej atrakcyjne zarówno dla pracodawców, jak i pracowników. Zawód freelancera staje się często naturalnym wyborem po skończeniu studiów. W świetle badań w sektorze małych i średnich przedsiębiorstw branży medycznej ${ }^{4}$ można zauważyć jednak słabnące zainteresowanie pracodawców zatrudnianiem pracowników na umowy cywilnoprawne, którzy dostrzegają obniżenie wpływu na zadaniowy charakter współpracy oraz słabnącą kontrolę w utrzymaniu relacji z pracownikami. Fundamentem klasycznego zatrudnienia jest kontrakt psychologiczny typu relacyjnego. Warunkuje on zasady współpracy określone przez pracodawcę, zasady zatrudnienia, zasady doskonalenia i awansu. „Dokonujące się przeobrażenia w sferze karier zawodowych polegają na przebudo-

\footnotetext{
${ }^{3}$ Kontrakt relacyjny to rodzaj umowy nienazwanej, która jest podstawą zaawansowanej współpracy oraz współdziałania w badanych klinikach. Podstawą zawierania kontraktu jest zaufanie stron wymiany.

${ }^{4}$ Badania prowadzone były w prywatnych wysokospecjalistycznych gabinetach stomatologicznych we Wrocławiu.
} 
wie relacji między jednostką i organizacją z zależnościowych na podmiotowe, co skutkuje przesunięciem odpowiedzialności za kształt i przebieg współpracy w stronę jednostki jako jej realizatora" [Bednarska-Wnuk, Januszkiewicz 2012, s. 190]. Freelancing zrodził wiele korzyści dla obu stron współpracy, ale również zmienił świadomość pracowników co do niezależności własnej i dysponowania swoim potencjałem. Relacje pracownik-pracodawca od zawsze mają specyficzny charakter i złożoną naturę, głównie ze względu na wyróżniające cechy kapitału ludzkiego w przedsiębiorstwie. Wyróżniające to zdolność do generowania wartości, unikatowość oraz trudność kopiowania, jak również ponadprzeciętna wrażliwość [Bombiak 2013, s. 147]. W spółczesna organizacja, w dobie hiperzmienności środowiska, postawiona jest przed koniecznością budowania takich kompetencji organizacji, aby w sposób świadomy i adekwatny do zmian sprawnie zarządzać swoim kapitałem ludzkim. Zachwianie dobrych relacji organizacji z pracownikami może rodzić wiele kosztów, do których przede wszystkim należy zaliczyć: koszty fluktuacji, koszty rekrutacji i selekcji, koszty związane z adaptacja i motywacją, koszty związane z utratą wiedzy i niewykorzystanych możliwości.

Jak wskazuje K. Mazur, ,pracownik może stanowić węzeł w sieci jedynie w przypadku, gdy będzie objęty umową (kontraktem) o formalnym lub nieformalnym charakterze, jeśli będzie miał wpływ na warunki kontraktu i będzie miał możliwość egzekwowania tych warunków, co oznacza, że będzie on traktowany jako partner" [Mazur 2015, s. 237-238]. W warunkach wysokiej niepewności na rynku pracy, zwłaszcza w relacjach pracownik-pracodawca, współdziałanie nabiera szczególnego wymiaru. E. Stańczyk-Hugiet i J. Gorgól nadają w takim przypadku pracownikowi tzw. „mikropozycję" partnera w biznesie na zasadach węzła sieci wewnątrzorganizacyjnej, której siła uwarunkowana jest efektywnością oraz jego zdolnością do tworzenia relacji oraz tworzenia i przechwytywania wartości [Mazur 2015, s. 19]. Rynek wolnego pracownika na współczesnym rynku pracy wymaga od pracodawców zmiany postaw i zachowań organizacyjnych w kierunku: poszanowania godności pracowników, inwestowania w rozwój, transparentnych zasad współpracy, wdrażania work-life balance, zapobiegania różnym przejawom dyskryminacji oraz poszanowania odmienności poglądów i potrzeb.

$\mathrm{W}$ organizacjach medycznych badanego sektora usług od kilku lat obserwuje się tendencję związaną z przechodzeniem lekarzy z umów o pracę na inne formy zatrudnienia ${ }^{5}$. Wybór ten jest uwarunkowany podejściem pracodawców tej branży. Klasyczny freelancing jest coraz popularniejszą formą aktywności zawodowej lekarzy w Polsce, zwłaszcza młodego pokolenia dentystów. Lekarze z dłuższym stażem preferują umowy o pracę, choć jest ich mniej niż jeszcze 5, 10 lat wcześniej. Co do zasady współpraca lekarzy z potencjalnym miejscem wykonywania zawodu odbywa się w oparciu o umowy cywilnoprawne, a działalność lekarza prowadzona jest na zasadach firmy jednoosobowej. Ciekawe jest również, w kontekście kształtowania

\footnotetext{
${ }^{5}$ Badany sektor to prywatne gabinety stomatologiczne we Wrocławiu.
} 
rynku oraz budowania kariery zawodowej, spojrzenie młodych dentystów, którzy planują prywatną praktykę dentystyczną tuż po uzyskaniu prawa do wykonywania zawodu. Młodzi lekarze dentyści chętniej deklarują samozatrudnienie niż ich starsi koledzy. Nieco ponad 70\% studentów ostatnich roczników na Wydziale Stomatologii we Wrocławiu planuje założenie własnego gabinetu w krótkim czasie od wejścia na rynek pracy. Zatem narasta i narastać będzie problem zatrudniania młodej kadry na coraz bardziej konkurencyjnym rynku pracy. Konkurencja o najlepszych kandydatów rozpoczyna się już na poziomie stażu podyplomowego. Zmianie ulegają również oczekiwania finansowe potencjalnych kandydatów, które stanowią niemałe wyzwanie dlapracodawców, zwłaszcza w pierwszych latach pracy mniej doświadczonych dentystów. Systemy płac są bowiem prowizyjne i wahają się od 30\% wartości usługi dla lekarzy bez specjalizacji do 50\% dla specjalistów. Zarobki 50\% stomatologów wahają się od $2308 \mathrm{zł}$ do $6240 \mathrm{zl}$ (brutto). Premia stanowi średnio 5\% pensji całkowitej stomatologa, natomiast $95 \%$ to płaca podstawowa plus benefity [Raport Sedlak \& Sedlak]. Oczekiwania lekarzy dentystów sięgają pułapu od $7000 \mathrm{zł}$ do $20000 \mathrm{zł}$ (netto) miesięcznie, co stanowi spore wyzwanie dla pracodawców w obecnych warunkach rynkowych (rys. 3).

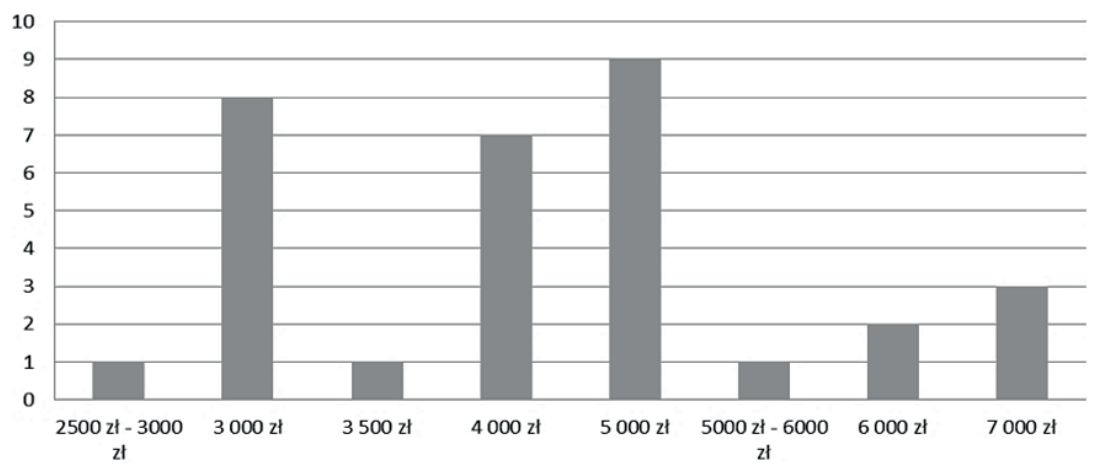

Rys. 3. Preferencje wynagrodzenia studentów kierunku stomatologia UM we Wrocławiu Źródło: opracowanie własne na podstawie badań empirycznych.

Co do preferencji zatrudnienia oraz sposobu współpracy na rynku pracy badania potwierdzają tendencję w zakresie oczekiwanych form zatrudnienia (rys. 4). Młodzi dentyści jako główną formę współpracy wskazują samozatrudnienie. Umowa o pracę w dużej klinice stanowi preferowaną formę dla co piątego młodego lekarza. Gabinety stomatologiczne, zarówno we Wrocławiu, jak i w Katowicach, stawiają natomiast na inwestowanie w młodych lekarzy, stąd dylemat: jak zatrzymać młodych dentystów po okresie zbierania doświadczeń i w czasie intensywnych szkoleń podczas stażu? Średni okres pracy lekarzy dentystów w gabinecie to 3-6 lat dla mężczyzn i 4-8 lat dla kobiet. Pracodawcy szacują, że okres 4-5 lat to czas niezbędny do zebrania minimum doświadczenia, aby w pełni wykonywać specjalistyczne proce- 
dury medyczne. Wraz jednak z czasem nabierania doświadczeń przez lekarzy młodego pokolenia ich oczekiwania finansowe rosną nieadekwatnie do przyrostu ich wiedzy i doświadczenia. Współpraca staje się w tym okresie coraz trudniejsza i stanowi punkt zwrotny w zderzeniu oczekiwań pracodawcy i pracownika. Prywatne gabinety, najczęściej zarządzane przez lekarzy-właścicieli, nie dysponują zaawansowanym systemem motywowania i nie radzą sobie z tak częstą rotacją specjalistów.

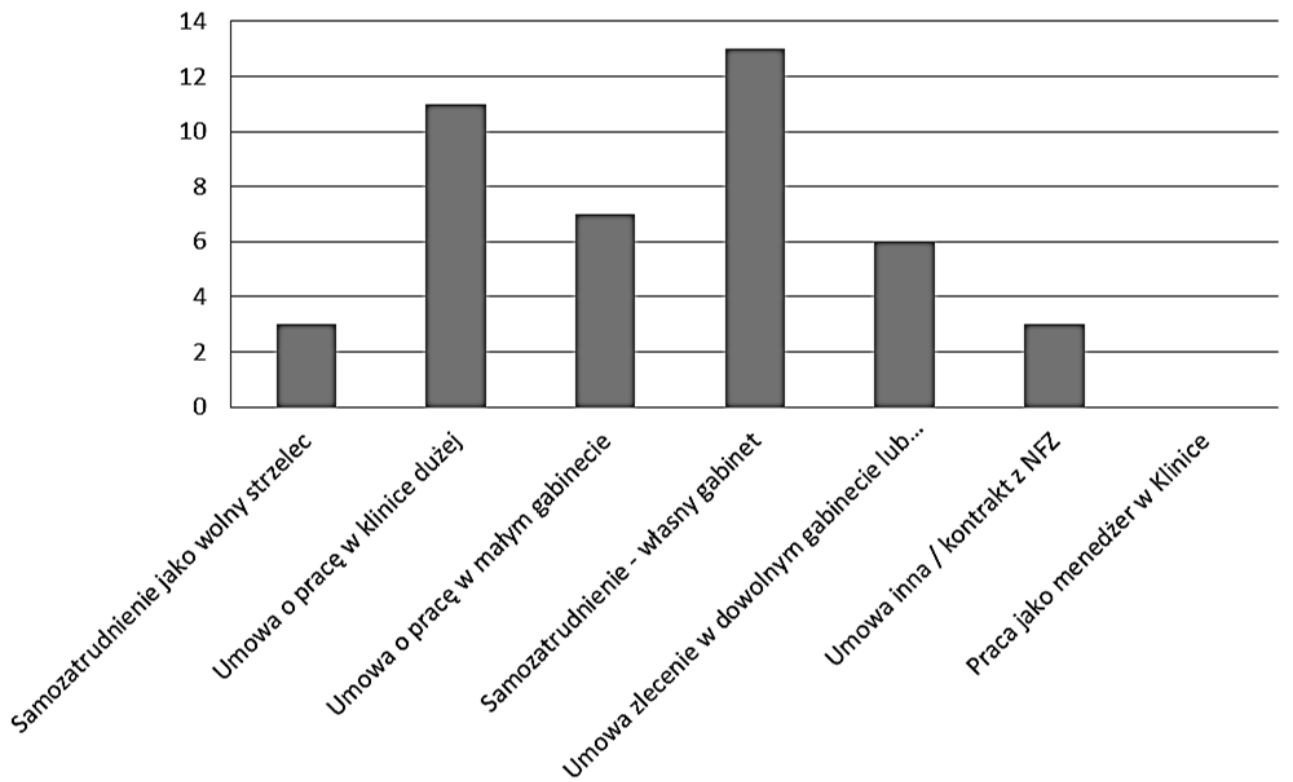

Rys. 4. Preferencje formy zatrudnienia lekarzy dentystów we Wrocławiu

Źródło: opracowanie własne na podstawie badań empirycznych.

Kluczowe wymagania stawiane przyszłym lekarzom, partnerom w nowoczesnym biznesie stomatologicznym, to: możliwości zdobywania nowej wiedzy, możliwość doskonalenia się, możliwość pracy w nowoczesnej infrastrukturze gabinetu oraz dobre relacje pracownik-pracodawca oraz pracownik-pracownik (rys. 5). Problem utrzymania pracownika też staje się coraz istotniejszy, zwłaszcza w dobie narastających pokus o przejmowanie uzdolnionych i doświadczonych lekarzy przez gabinety konkurencji.

Oczekiwania pracodawców wobec młodych lekarzy to: zaangażowanie w pracę nie tylko z pacjentem, chęć zdobywania nowej wiedzy i udział w szkoleniach, gotowość do samodoskonalenia, jak również lojalność wobec pracodawcy i otwartość na pracę $\mathrm{w}$ zespole specjalistów.

W oparciu o wyniki tych samych badań można stwierdzić, że młodzi ludzie nie planują wyjeżdżać za granicę $\mathrm{w}$ poszukiwaniu pracy i jest to zgodne $\mathrm{z}$ dotychczasową tendencją która od lat utrzymuje się na podobnym poziomie. Wśród specjalności 


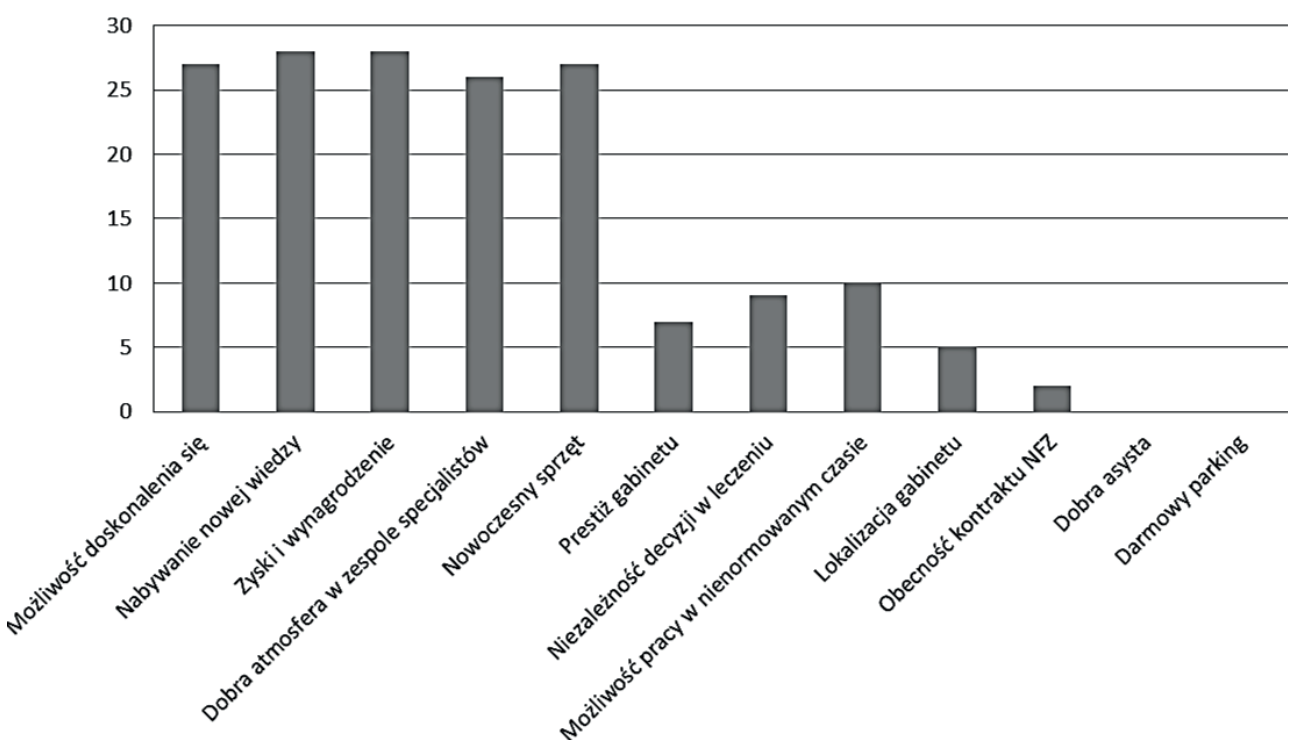

Rys. 5. Determinanty współpracy lekarzy dentystów we Wrocławiu

Źródło: opracowanie własne na podstawie badań empirycznych.

medycznych stomatolodzy są na ostatnim miejscu pod względem wyjazdów zagranicznych związanych z pracą (dane NIL). Forma freelancingu staje się normą rynkową i nie jest wybiegiem kliniki w kierunku obniżenia kosztów. Forma ta coraz częściej budzi jednak wątpliwości wśród pracodawców, głównie ze względu na osłabione relacje pracodawca-pracownik i niższy poziom lojalności wobec kliniki. Lekarze stają się graczami na rynku kontraktów relacyjnych i wchodzą do sieci różnych klinik jako wolni partnerzy „do wynajęcia”. Kliniki nie znają mechanizmów utrzymania poczucia bezpieczeństwa $\mathrm{w}$ długofalowych procesach inwestowania w specjalistów, bowiem trend ujawnia intensywne przechwytywanie wiedzy, a następnie ich sprzedaż. Lekarze to „,pracownicy wiedzy posiadający unikalne kompetencje, których wykorzystanie kreuje wartość dodaną w nowoczesnych produktach i technologiach" [Skrzypek 2002, s. 679], generując tym samym unikatowość kluczowych kompetencji dla klinik stomatologicznych badanej branży. Branża medyczna nasycona jest wyłącznie pracownikami wiedzy, co zmienia percepcję pozyskiwania i utrzymania pracowników w przedsiębiorstwie, tym samym staje się to coraz trudniejsze ze względu na mobilność kapitału ludzkiego oraz silne poczucie niezależności.

Jeśli przyjąć za K. Mazur, że pracownik jako partner w sieci stanowi zasób o szczególnych cechach, posiada zdolności tworzenia wartości oraz przechwytywania ich, to koszty utraty takiego pracownika mogą stanowić poważne zagrożenie dla organizacji. Zagrożenia te leżą głównie w utracie kompetencji, które trudno uzupeł- 
nić w krótkim czasie, utracie informacji i wiedzy po odejściu pracownika, wykorzystaniu informacji na rzecz konkurencji, które są źródłem utraty pozycji konkurencyjnej. Zasadniczym kosztem organizacji po utracie pracownika jako cennego zasobu jest zdolność przedsiębiorstwa do odtworzenia luki kompetencyjnej i zasobów relacyjnych. Badane kliniki potwierdzają powyższe czynniki zagrożenia i uznają je za kluczowe.

\section{Podsumowanie}

Współczesny rynek pracy, dominujący jako rynek pracownika, budzi szereg obaw zwłaszcza wśród pracodawców badanego sektora medycznego. Stały deficyt doświadczonych lekarzy dentystów rodzi problemy już na etapie rekrutacji. Proces pozyskania nowego pracownika staje się coraz dłuższy mimo coraz bardziej zaawansowanych metod i form rekrutacji. Rosnące oczekiwania finansowe przy jednoczesnym niskim poziomie wiedzy młodych kandydatów do pracy stawiają organizacje w niezwykle trudnym położeniu i rodzą refleksje dotyczące kierunku rozwoju, sposobów zarządzania, filozofii budowania relacji z dotychczasowymi pracownikami oraz potrzebą poszukiwań nowych rozwiązań dotyczących budowania relacji z młodym pokoleniem pracowników. Badania w klinikach ukazują rozwarstwienie między oczekiwaniami pracowników i pracodawców. Obawy pracodawców budzą również: niski poziom zaangażowania młodych lekarzy stażystów, brak chęci samodoskonalenia, wysokie oczekiwania finansowe przy jednocześnie niskim poziomie wiedzy i umiejętności. Istotnym ograniczeniem pracodawców jest brak efektywnych mechanizmów zatrzymania pracowników o wysokim potencjale i doświadczeniu. Wyzwaniem zatem stają się nowe sposoby poszukiwania, zatrudniania i utrzymania pracowników badanej branży. Budowanie trwałych relacji pracowników i pracodawców jest potencjalnym źródłem przewagi konkurencyjnej na rynku usług medycznych. Utrzymanie tych relacji jest też gwarantem utrzymania klientów oraz pomnażania wartości dla wszystkich zaangażowanych stron w sieci tych relacji.

\section{Literatura}

Bednarska-Wnuk I., Januszkiewicz K., 2012, Oblicza kariery w XXI wieku, Uniwersytet Ekonomiczny w Krakowie, Kraków.

Bombiak E., 2013, Ksztaltowanie relacji z pracownikami jako płaszczyzna społecznej odpowiedzialności biznesu, Zeszyty Naukowe Uniwersytetu Przyrodniczo-Humanistycznego w Siedlcach, nr 99, Seria: Administracja i Zarządzanie.

Brilman J., 2002, Nowoczesne koncepcje i metody zarządzania, PWE, Warszawa.

Chomiak-Orsa I., 2013, Zarządzanie kapitałem relacyjnym $w$ procesie wirtualizacji organizacji, Wydawnictwo Uniwersytetu Ekonomicznego we Wrocławiu, Wrocław.

Doligalski T., 2013, Internet w zarządzaniu wartością klienta, Oficyna Wydawnicza Szkoła Główna Handlowa w Warszawie, Warszawa. 
Falencikowski T., 2013, Spójność modelu biznesu. Koncepcja i pomiar, CeDeWu, Warszawa.

Kaczmarek B., 2000, Współdziałanie przedsiębiorstw w gospodarce rynkowej, Wydawnictwo Uniwersytetu Łódzkiego, Łódź.

Kwartalny raport o rynku pracy w IV kwartale 2014 r., nr 1/15 (marzec 2015 r.), Narodowy Bank Polski, Biuro Przedsiębiorstw, Gospodarstw Domowych i Rynków, Instytut Ekonomiczny, Warszawa.

Lipka A., 2004, Współdziałanie. Zmierzch rywalizacji pracowników, Difin, Warszawa.

Magretta J., 2002, Why business models matter?, Harvard Business Review, May.

Magretta J., 2003, What Management Is?, Profile Books, London.

Mazur K., 2015, Sieci międzyorganizacyjne, [w:] Krupski R. (red.), Zarzadzanie strategiczne: strategie sieci i przedsiębiorstw w sieci, Wydawnictwo Wałbrzyskiej Wyższej Szkoły Zarządzania i Przedsiębiorczości w Wałbrzychu, Wałbrzych.

Mikuła B., 2012, Nowy wymiar zachowań organizacyjnych, [w:] Mikuła B. (red.), Zachowania organizacyjne w kontekście zarządzania wiedza, Fundacja Uniwersytetu Ekonomicznego w Krakowie, Kraków.

Polak J., 2016, Wspótpraca i współdziałanie międzyorganizacyjne w telekomunikacji mobilnej, Studia Ekonomiczne, Zeszyty Naukowe Uniwersytetu Ekonomicznego w Katowicach, nr 299.

Raport Sedlak \& Sedlak, wynagrodzenia.pl, https://sedlak.pl/ (18.08.2017).

Raport z badań: Oczekiwania, aspiracje, obawy. Młody lekarz dentysta w ankietowym badaniu online, infoDENT24.pl, PTSS i BAD, http://www.infodent24.pl/bizdentpost/oczekiwania-aspiracjeobawy-mlody-lekarz-dentysta-w-ankietowym-badaniu-online-infodent24-pl-ptss-i-bad,100821. html (12.06.2016).

Skrzypek E., 2002, Miejsce zarzadzania informacja i wiedza w strategii przedsiębiorstwa, [w:] Stabryła A. (red.), Zarządzanie firma w spoteczeństwie informacyjnym, Wydawnictwo EJB, Kraków.

Sobińska M., 2015, Przewodnik sourcingu IT, Wydawnictwo Uniwersytetu Ekonomicznego we Wrocławiu, Wrocław.

Stańczyk-Hugiet E., Gorgól J., 2012, Elementy sieci międzyorganizacyjnych - aspekty organizacyjno-zarzadcze, [w:] Niemczyk J., Stańczyk-Hugiet E., Jasiński B. (red.), Sieci międzyorganizacyjne. Wspótczesne wyzwania dla teorii i praktyki zarządzania, Wyd. C.H. Beck, Warszawa. 